\title{
Pemodelan Arsitektur Sistem Informasi untuk Mendukung Aktivitas Akademik di STIMIKOM Stella Maris Sumba
}

\author{
Yulius Nahak Tetik $^{*}$, Wing Wahyu Winarno ${ }^{2}$, Eko Pramono ${ }^{3}$ \\ ${ }^{1}$ Program Pasca Sarjana, Universitas Amikom, Yogyakarta, Indonesia \\ ${ }^{2,3}$ Dosen Universitas Amikom, Yogyakarta, Indonesia \\ Email: ${ }^{1 *}$ yuliusteti@gmail.com, ${ }^{2}$ wing@amikom.ac.id, ${ }^{3}$ eko.p@ amikom.ac.id
}

\begin{abstract}
Abstrak
Teknologi Informasi dan sistem informasi menjadi suatu kebutuhan yang sangat fundamental dalam mendukung fungsi bisnis pada suatu organisasi atau perusahaan baik itu pemerintah, swasta. Ditengah lajunnya perkembangan teknologi informasi, perguruan tinggi ditantang untuk menerapkan teknologi informasi dan sistem informasi yang dapat memudahkan dan mempercepat pelayanan, baik kepada mahasiswa, dosen maupun masyarakat umum dalam hal mendaptkan informasi. Dalam mengembangkan sebuah sistem informasi, perlu adanya perencanaan yang baik untuk jangka pendek, menengah maupun jangka panjang agar sistem yang telah dibangun dapat terus dikembangkan seiring dengan pembangunan sistem yang baru. Enterprise Architecture Planning merupakan suatu metodologi yang dapat digunakan untuk membangun arsitektur sistem secara terstruktur yang dimulai dari perencenaan sampai pada tahap perencanaan implentasi. Pada jurnal peneltian ini, akan dibahas penggunaaan Enterprise Architecture Planning dalam membuat arsteektur sistem informasi untuk mendukung aktivitas akademik berupa arsitektur data, aplikasi dan teknologi
\end{abstract}

Kata Kunci: Arsitektur, sistem, informasi, aplikasi, data

\begin{abstract}
Information technology and information systems are a very fundamental requirement in supporting business functions in an organization or company, whether government or private. Amid the rapid development of information technology, universities are challenged to implement information technology and information systems that can facilitate and accelerate services, both to students, lecturers and the general public in terms of obtaining information. In developing information systems, there needs to be careful planning for the short, medium and long term so that the system that has been built can continue to be developed together with the construction of a new system. Enterprise Architecture Planning is a methodology that can be used to build a structured system architecture starting from planning to the implementation planning stage. In this journal, we will discuss the use of Enterprise Architecture Planning in creating information system architecture to support academic activities in the form of data architecture, applications and technology
\end{abstract}

Keywords: Architecture, System, information, Aplications, data

\section{PENDAHULUAN}

Pemanfaatan teknologi informasi dan sistem informasi dewasa ini menjadi suatu kebutuhan yang sangat penting bagi setiap organisasi baik pemerintah, swasta dalam meningkatkan tata kelola organisasinya. Dalam bidang pendidikan khususnya Perguruan Tinggi, pemanfaatan teknologi informasi dan sistem informasi dapat dikatakan sebagai suatu solusi yang sangat fundamental di tengah lajunya perkembangan teknologi informasi dan sistem informasi terhadap pelayanan administrasi maupun kegiatan belajar mengajar.

STIMIKOM Stella Maris Sumba merupakan salah satu Perguruan Tinggi di Kabupaten Sumba Barat Daya yang menyelenggarakan pendidikan dan pengajaran di bidang ilmu komputer yang terdiri dari dua program studi yaitu Teknik Informatika jenjang Strata 1 (S1) dan Manajemen Informatika jenjang Diploma Tiga (D-III). Sebagai salah satu Perguruan Tinggi, di tengah lajunya penerapan teknologi informasi dan sistem informasi STIMIKOM Stella Maris Sumba ditantang untuk cepat dalam mengelolah data dan informasi kegiatan akademik maupun pelayanan administrasi akademik, namun dalam menjalankan kegiatan akademik maupun pengolahan data khususnya pada Biro Administrasi Akademik dan Kemahasiswaan (BAAK) sering mengalami kendala seperti keterlambatan pelaporan data mahasiswa baru, pengolahan data rencana studi mahasiswa, data nilai mahasiswa, penjadwalan proses belajar dan mengajar karena masih dilakukan secara konvensional. Untuk mengatasi berbagai permasalahan di atas, maka perlu diterapkannya sebuah sistem informasi. Namun, dalam membangun sebuah sistem informasi yang kompleks, perlu adanya arsitektur sistem yang dapat dijadikan sebagai acuan baik untuk jangka pendek, menengah maupun jangka panjang. Menurut [1], keberhasilan implementasi dan penerapan sistem informasi dipengaruhi oleh faktor perencanaan yang matang oleh para stakeholder dan tersediannya sumber daya, teknologi dan infrastruktur pendekatan yang gunakan dalam memodelkan arsitektur sistem inforamasi untuk mendukung akademik di STIMIKOM Stella Maris Sumba yaitu Enterprises Architecture Planning (EAP).

\section{TEORITIS}

\subsection{Kerangka Kerja Zachman}

Kerangka kerja Zachman merupakan sebuah skema atau struktur dasar yang digunakan untuk menggambarkan dan mendefenisikan suatu keadaan enterprise. Kerangka kerja Zachman bukan merupakan metodologi yang dapat 
digunakan untuk membuat implementasi pada suatu objek melainkan sebuah struktur dalam menetapkan defenisi, sedangkan proses adalah tahapan yang dilakukan untuk menyiapkan perubahan. [2]. Menurut [3], pemanfaatan kerangka kerja Zachman sebagai suatu metodologi meliputi semua aspek dalam arsitektur enterprise atau aspek apa sja yang merupakan cakupan dalam metodologi. Kerangka kerja Zachman terdiri dari 6 (enam) kolom dan 6 (enam) baris sehingga kerangka kerja Zachman sering disebut dengan matriks 6 x 6 . Berikut ini adalah gambar kerangka kerja Zachman yang ditunjukan pada gambar 1 dibawah ini.

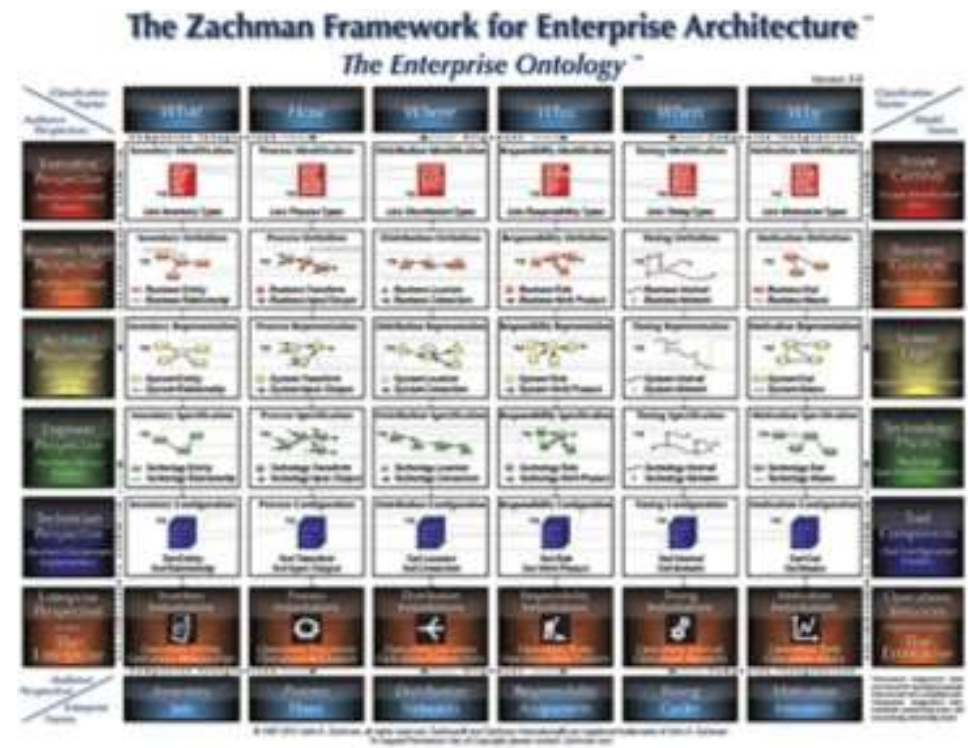

Gambar 1. Kerangka Kerja Zachman [2].

Setiap kolom pada contoh gambar 1 diatas merepresentasikan fokus, topik arsitektur enterprise (abstraksi), meliputi : Data, fungsi, jaringan, manusia, waktu, dan motivasi, sedangan tiap baris merepresentasikan perspektif perencana, pemilik, perancang, pembuat, subkontraktor, dan fungsional.

Cakupan EAP pada kerangka kerja Zachman berada pada baris pertama dan baris kedua yang merupakan perspektif dari planner (perencana) dan Owner (pemilik), sedangkan pembahasan dalam EAP terdapat pada kolom pertama, kedua dan kolom ketiga meliputi pembahasan terkait data, fungsi dan jaringan pada arsitektur sistem informasi yang dibangun.

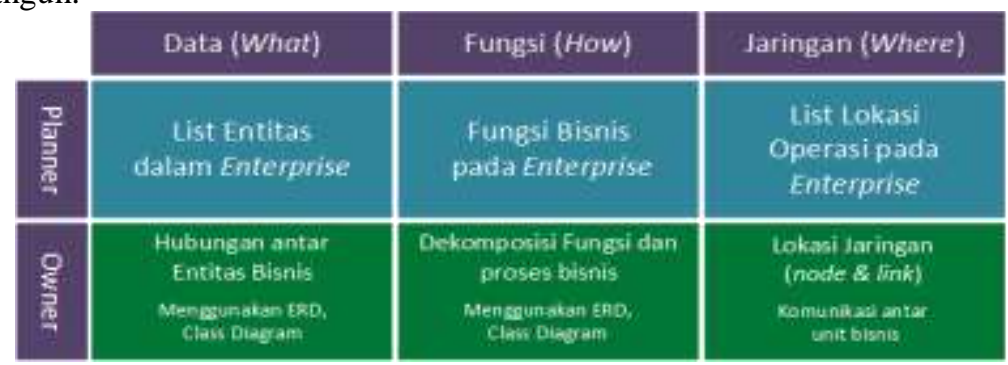

Gambar 2. Cakupan EAP pada kerangka Kerja Zachman

\subsection{Enterprise Arsitektur Planning (EAP)}

Enterprise Architecture Planning adalah sebuah teknik mendefenisikan arsitektur untuk penerapan informasi dalam mendukung bisnis dan membuat rencana implementasi arsitektur. EAP juga dapat dikatakan sebagai suatu pendekatan yang dapat menggambarkan, atau memvisualisasikan keaadaan dan kondisi saat ini maupun yang akan datang dilingkungan enterprise secara lengkap dan logis [4] EA merupakan kumpulan rencana yang terstruktur dan selaras yang diberikan sebagai reppresentasi hubungan antara bisnis dan teknologi informasi saat ini maupun di masa yang akan datang [5].

Menurut [6], Enterprise Architecture adalah salah satu media atau sarana yang digunakan untuk mendefenisikan strategi dari suatu organisasi dari berbagai sudut padang terhadap proses bisnis, sistem, maupun teknologi dari organisasi.

Dari ketiga pernyataan diatas dapat disimpulkan bahwa Enterprise Architecture Planning dapat digunakan untuk mengidentifikasi proses (aktivitas) bisnis, membangun dan merenanakan implementasi arsitektur sistem informasi dan teknlogi informasi dalam mendukung proses bisnis kedepannya.

EAP terdiri dari 4 (empat) lapisan (layer) dan terbagi menjadi 7 (tujuh) komponen atau elemen yang merupakan tahapan-tahapan dalam menentukan, membuat dan merencanakan imlementasi arsitektur sistem 
informasi yang telah didefenisikan. Berikut ini adalah 7 (tujuh) komponen dari EAP yang ditunjukan pada gambar 3.

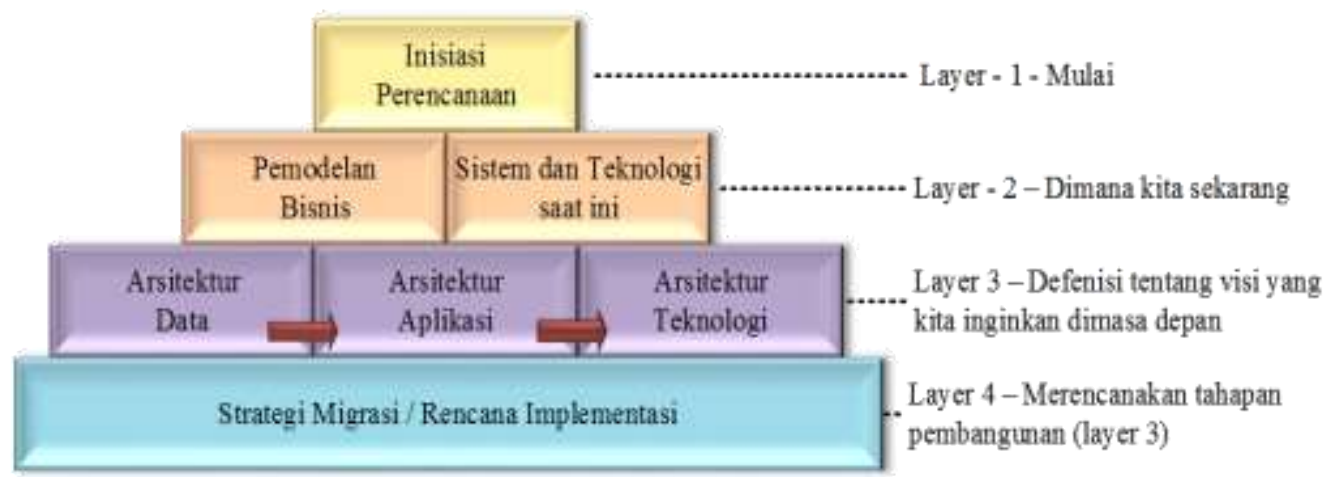

Gambar 3. Lapisan Perencanaann Arsitektur Enterprise [4]

Tahapan-tahapan pemodelan arsitektur dengan pendekatan enterprise arsitektur planning pada gambar 3 diatas dapat dijelaskan sebagai berikut :

a. Tahap 1. Inisiasi Perencanaan : Merupakan tahapan yang berfungsi unutk mengidentifikasi aturan terkait rujukan dalam membuat arsitetur sistem informasi dan menentukan ruang lingkup enterprise, serta visi dan misi dari arsitektur yang akan dibangun.

b. Tahap 2. Pemodelan Bisnis : Merupakan tahapan yang bertujuan untuk membangun basis pengetahuan tentang bisnis dan informasi yang digunakan pada lingkungan enterprise saat ini serta mendefenisikan model bisnis lebih komprehensif dan lengkap sehingga dapat dijadikan sebagai suatu landasan dalam memodelkan arsitektur-arsitektur dan rencana implementasi. Selain tujuan yang telah disebutkan, tahap ini juga digunakan untuk megidentifikasi, mendokumentasikan struktur organisasi yang ada pada enterprise, menentukan area bisnis. Proses identifikasi area bisnis dapat dilakukan dengan menggunakan model rantai nilai (value chain)

c. Tahap 3. Sistem dan teknlogi saat ini : Adapaun tujuan dari tahap ini yaitu untuk melakukan identifikasi dan mendokumentasikan sistem maupun platform yang saat ini digunakan oleh enterprise dalam mendukung aktivitas bisnis

d. Tahapan pemodelan arsitektur enterprise sistem masa depan : Pada tahapan ini tebagi menjadi tiga proses diantaranya proses pemodelan Arsitektur data, proses pemodelan Arsitektur Aplikasi, dan proses pemodelan Arsitektur Teknlogi.

1. Pemodelan arsitektur data

Proses ini bertujuan untuk mengidentifikasi dan mendefenisikan jenis-jenis data dengan cara mengidentifikasi dan membuat daftar entitas data utama yang dibutuhkan dalam mendukung bisnis.

2. Pemodelan arsitektur aplikasi

Pada proses ini bertujuan untuk mengidentifikasi dan mendefenisikan jenis-jenis aplikasi utama yang relevan dengan enterprise berdasarkan hasil identifikasi yang dilakukan sebelumnya pada entitas-entitas data. Kandidat-kandidat aplikasi yang telah diidentifikasi kemudian direlasikan dengan fungsi bisnis enterprise.

3. Pemodelan arsitektur teknologi

Pada tahapan ini dilakukan dengan tujuan untuk mengidentifikasi dan mendefenisikan prinsip teknologi yang akan diterapkan pada lingkungan enterprise didalam mendukung arsitektur aplikasi yang telah didfenisikan sebelumnya.

e. Tahapan rencana implementasi : Tahapan ini bertujuan untuk membuat rencana implementasi berupa rekomendasi atau usulan jenis aplikasi yang telah didefenisikan pada arsitektur aplikasi dengan cara mengurutkan jenis-jenis aplikasi yang disertai dengan estimasi kebutuhan pada saat implementasi atau jangka waktu yang dibutuhkan dalam implementasi setiap aplikasi.

\subsection{Rantai Nilai (value chain)}

Rantai nilai (value chain) adalah salah satu strategi yang digunakan untuk menganalisis kegiatan atau aktivitas di lingkungan enterprise meliputi aktivtas utama maupun aktivitas pendukung guna meminimalisir biaya yang akan dikeluarkan.

Menurut [7], untuk mendapatkan keunggulan kompetitif, perusahaan (enterprise) harus membuat proposisi terhadap nilai produk yang berbeda dalam memenuhi kebutuhan pelanggan atau konsumen dengan cara melakukan analisis rantai nilai terhadap serangkaian kegiatan mulai dari membuat, memproduksi dan medistribusikan atau mengirim kepada konsumen. 

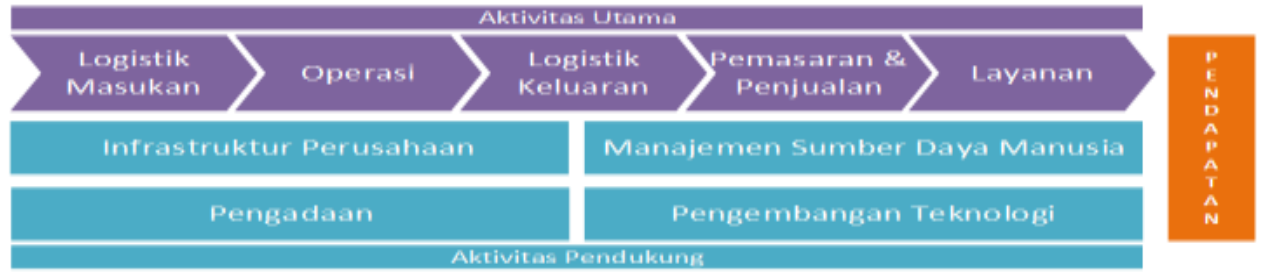

Gambar 4. Rantai Nilai (value chain)

Pada gambar 4 diatas, analisis rantai nilai dibagi menjadi 2 jenis aktivitas yaitu :

a. Akitivitas utama (primary activity)

1. Logistik masukan : aktivitas pada perusahaan yang berkaitan dengan penanganan terhadap bahan baku sebelum digunakan

2. Operasi : aktivitas pada enterprise yang berkaitan bagaimana mentransformasikan masukan (input) menjadi keluaran (outoput)

3. Logistik keluaran : aktivitas pada perusahaan yang berkaitan dengan penyebaran (distribusi) produk kepada konsumen atau pelanggan

4. Pemasaran dan Penjualan : akivitas pada enterprise yang berkaitan dengan penjualan dan pemasaran seperti promosi produk yang akan dijual

5. Layanan : aktivitas pada perusahaan yang berkaitan dengan penyediaan layanan guna mempertahankan atau meningkatkan pemeliharaan produk.

b. Aktivitas pendukung (support activity)

1. Infrastruktur Perusahaan : Aktivitas pada perusahaan yang berkaitan dengan pengelolaan keuangan, aset, keamanan dan keselamatan maupun fungsi pelayanan kebutuhan lainnya

2. Manajemen Sumber Daya Manusia : Aktvitas pada perusahaan yang berkaitan dengan rekrutmen, pelatihan, pengembangan diri dan kompensasi bagi semua personil dalam perusahaan.

3. Pengadaan : Aktivitas pada perusahaan yang berkaitan dengan bagaimana sumber daya diperoleh

4. Pengembangan Teknologi : Aktivitas pada perusahaan yang berkaitan dengan pengembangan perangkat atau peralatan yang dapat mendukung produksi, pelayanan kepada pelanggan berbasis komputer

\section{METODE PENELITIAN}

Metode penelitian yang penulis gunakan pada penelitian ini yaitu metodologi kualitatif. Menurut [8], Metodologi penelitian kualitatif dipilih karena pemelihan dan analisis terhadap data yang diperoeh memanfaatkan setiap individu yang terkait atau terlibat dengan objek penelitian. Penelitian kualitatif sangat menekankan pada keakuratan data yang diperoleh karena semakin akurat data yang didapatkan maka hasil penelitian akan semakin berkualitas.

Adapun beberapa tahapan penelitian yang dilakukan meliputi studi literatur, observasi, wawancara, pengumpulan data, identifikasi model bisnis, identifikasi system saat ini dan teknologi serta pemodelan arsitektur sistem informasi. Pada pemodelan arsitektur, pendekatan yang penulis gunakan dalam membuat arsitektur sistem informasi untuk mendukung kegiatan akademik di STIMIKOM Stella Maris Sumba ini mengacu pada komponenkomponen Enterprise Arsitektur Planning yang meliputi inisiasi perencanaan, pemodelan bisnis, sistem dan teknologi saat ini, arsitektur data, arsitektur aplikasi dan rencana implemnetasi. Berikut ini adalah alur penelitian yang ditunjukan pada gambar 5.

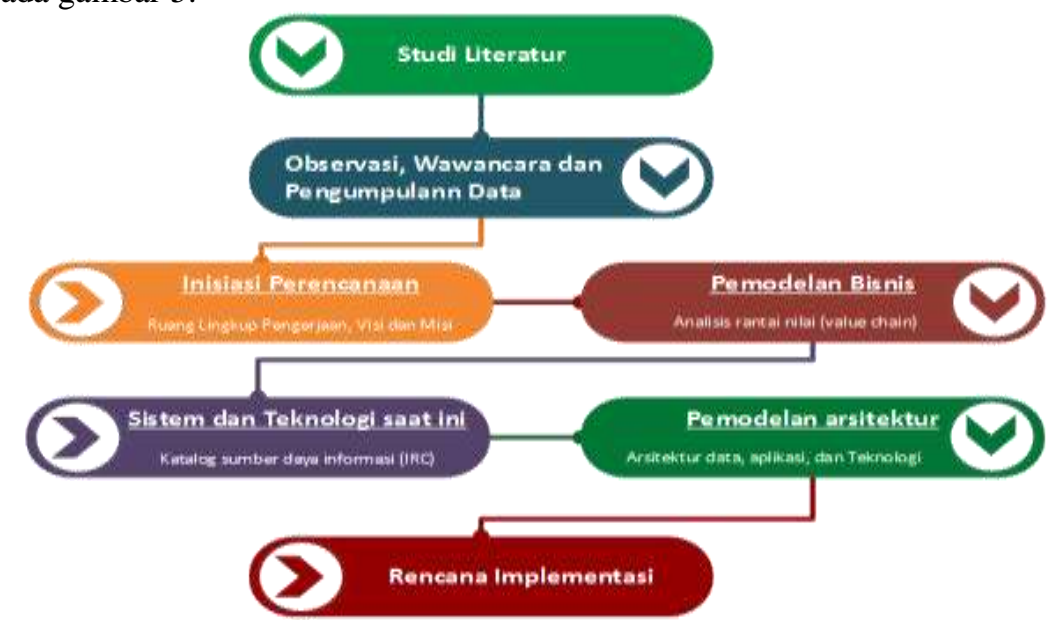

Gambar 5. Tahapan Penelitian

Yulius Nahak Tetik | http://ejurnal.stmik-budidarma.ac.id/index.php/mib | Page 211 
Berikut ini penjelasan dari masing-masing tahapan yang akan dilakukan :

a. Studi Literatur : merupakan tahapan yang dilakukan dengan tujuan untuk mencari referensi atau teori yang relevan dengan tema yang dibahas pada penelitian ini tentang pemodelan arsitektur sistem informasi dari jurnal atau artikel-artikel ilmiah, maupun buku

b. Observasi, wawancara, dan pengumpulan data : merupakan tahapan yang dilakukan dengan cara mengamati dari dekat obyek yang diteliti dan wawancara terkait permasalahan yang ada dengan para stakeholder di STIMIKOM Stella Maris Sumba serta pengambilan data dengan tujuan untuk menganalisa guna menemukan solusi atas permasalahan yang ada.

c. Inisiasi pengerjaan

Merupakan tahapan yang dilakukan dalam menentukan ruang lingkup enterprise dan sasaran pengerjaan proyek yang akan dilakukan

d. Pemodelan bisnis

Merupakan tahapan dalam menganalisa dan mendefenisiskan fungsi-fungsi bisnis pada STIMIKOM Stella Matris Sumba dengan menggunakan analisis rantai nilai (value chain)

e. Sistem dan teknologi saat ini

Merupakan tahapaan yang dilakukan dengan tujuan untuk mendapatkan gambaran terkait dengan sistem dan teknologi yang saat ini di terapkan di STIMIKOM Stella Maris sumba

f. Pemodelan Arsitektur :

Merupakan tahap inti pada penelitian ini yaitu membuat arsitektur sistem informasi dengan pendekatan EAP meliputi pemodelan arsitektur data, aplikasi dan arsitektur teknologi yang dapat dijadikan sebagai usulan bagi STIMIKOM Stella Maris Sumba untuk mengembangkan sistem informasi

g. Rencana Implementasi

Merupakan tahapan rencana pengembangan atau pembangunan sistem informasi meliputi jangka waktu yang dibutuhkan dalam dari setiap aplikasi.

\section{ANALISA DAN PEMBAHASAN}

\subsection{Inisiasi Perencanaana}

Tahapan inisiasi perencanaan ini bertujuan untuk menjabarkan ruang lingkup, visi dan misi dari STIMIKOM Stella Maris Sumba yang nantinya menjadi dasar dalam memodelkan arsitektur sistem informasi.

a. Ruang lingkup

Adapun ruang lingkup enterprise yang dipilih dalam membuat arsitektur sistem informasi ini yaitu pada pada Biro Administrasi Akademik dan Kemahasiswaan di STIMIKOM Stella Maris Sumba dengan berfokus pada masalah atau kendala pada kegiatan akademik.

b. Visi dan misi

Berikut ini adalah visi dan misi STIMIKOM Stella Maris Sumba yang penulis kutip dari Rencana Strategis (RENSTRA) STIMIKOM Stella Maris Sumba tahun 2014.

1. Visi

Menjadi Sekolah Tinggi yang unggul dibidang komputer, yang berbasis kewirausahaan serta memiliki karakter yang bersumber pada nilai-nilai Pancasila, berstandar nasional tahun 2021

2. Misi

i. Mengembangkan dan meningkatkan kegiatan Tridharma termasuk mengembangkan program unggulan dengan memanfaatkan potensi dan peluang yang ada.

ii. Mengembangkan kapasitas tatakelola organisasi yang berlandaskan pada sistem penjaminan mutu.

iii. Meningkatkan kualitas lulusan sesuai dengan bidang ilmu yang dipelajarinya untuk memenuhi tuntutan pengguna lulusan/stakeholders.

iv. Meningkatkan motivasi sivitas akademika dalam mengembangkan akademik atmosfer yang kondusif.

v. Meningkatkan perluasan kerjasama antar PT dan Institusi lain baik dalam dan luar negeri.

Berdasarkan visi dan misi yang telah di deskripsikan diatas, maka dapat disimpulkan bahwa yang menjadi poin utama peneltian ini dalam membuat atau memodelkan arsitektur sistem informasi yaitu poin 1 (satu) dan poin 2 (dua) pada Misi STIMIKOM Stella Maris Sumba.

\subsection{Pemodelan Bisnis}

Tahapan ini digunakan untuk menghimpun pengetahuan dan mendefenisikan bisnis yang dilakukan oleh STIMIKOM Stella Maris Sumba khususnya yang berkaitan dengan kegiatan akademik menggunakan analisis rantai nilai (value chain) meliputi aktivitas utama maupun aktivitas pendukung seperti yang tampak pada gambar 6 dibawah ini. 


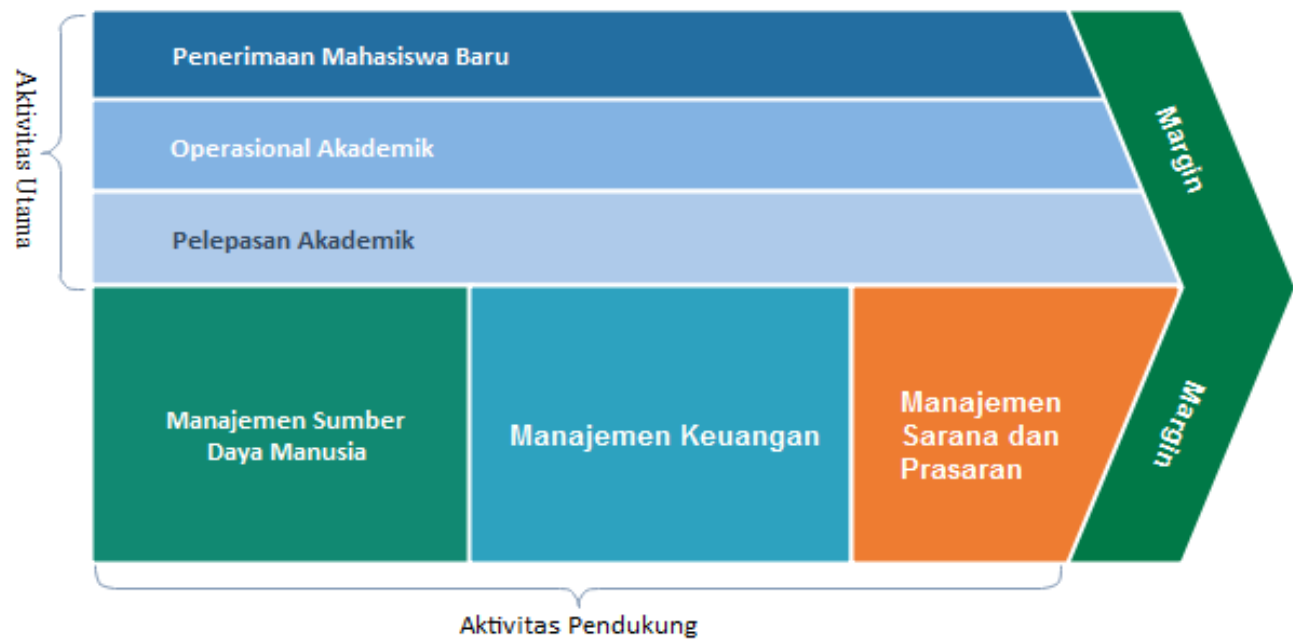

Gambar 6. Rantai nilai (value chain) STIMIKOM Stella Maris Sumba

Dari gambar 5 di atas, berikut ini tabel urain dari masing-masing fungsi berdasarkan aktivitasnya.

Tabel 1. Aktivitas Aktivitas Utama

\begin{tabular}{|c|c|c|}
\hline No & Nama Proses & Deskripsi Proses \\
\hline 1. & $\begin{array}{l}\text { Penerimaan } \\
\text { Mahasiswa Baru }\end{array}$ & $\begin{array}{l}\text { Pada proses ini meliputi semua aktivitas yang dimulai dari tahapan } \\
\text { rencana jadwal penerimaan mahasiswa baru, pembentukan panitia } \\
\text { seleksi, proses pendaftaran, proses seleksi masuk dan pendaftaran } \\
\text { ulang bagi mahasiswa yang lulus dalam proses seleksi masuk. }\end{array}$ \\
\hline 2. & $\begin{array}{l}\text { Operasional } \\
\text { Akedemik }\end{array}$ & $\begin{array}{l}\text { Proses ini meliputi seluruh aktivitas antara lain : Pembuatan } \\
\text { kurikulum, penentuan atau penunjukan dosen pengampu mata } \\
\text { kuliah, penunjukan dosen pembimbing akademik, perwalian } \\
\text { mahasiswa, pembuatan KTM, pembuatan KRS, Jadwal KBM di } \\
\text { kelas, Unian (UTS dan UAS), Pengolahan data nilai dan } \\
\text { pendaftaran seminar proposal, pendaftaran seminar skripsi dan } \\
\text { pelaporan data akademik ke DIKTI (feeder). }\end{array}$ \\
\hline 3. & $\begin{array}{l}\text { Pelepasan } \\
\text { Mahasiswa }\end{array}$ & $\begin{array}{l}\text { Pada proses ini meliputi pendaftaran yudisium, pendaftaran wisuda } \\
\text { bagi mahasiswa yang telah memenuhi syarat kelulusan, pembuatan } \\
\text { Ijazah dan Transkrip Nilai. }\end{array}$ \\
\hline
\end{tabular}

Tabel 2. Aktivitas Aktivitas Pendukung

\begin{tabular}{cll}
\hline No & \multicolumn{1}{c}{ Nama Proses } & \multicolumn{1}{c}{ Deskripsi Proses } \\
\hline 1. & $\begin{array}{l}\text { Manajemen Sumber } \\
\text { Daya Manusia }\end{array}$ & $\begin{array}{l}\text { Meliputi seluruh aktivitas yang berkaitan dengan pengalokasian } \\
\text { sumber daya manusia, rekrutmen dosen atau pegawai di } \\
\text { STIMIKOM Stella Maris Sumba, monitoring dan evaluasi kinerja } \\
\text { tenaga pendidik maupun tenaga kependidikan }\end{array}$ \\
\hline 2. & $\begin{array}{l}\text { Manajemen } \\
\text { Keuangan }\end{array}$ & $\begin{array}{l}\text { Semua kegiatan penganggaran untuk kebutuhan kampus, } \\
\text { pemeliharaan fasilitas atau infrastruktur dan pelaporan keuangan }\end{array}$ \\
\hline 3. & $\begin{array}{l}\text { Manajemen Sarana } \\
\text { Prasarana }\end{array}$ & $\begin{array}{l}\text { Pada proses ini meliputi semua kegiatan yang berkaitan dengan - } \\
\text { pengelolaan sarana dan prasarana, maupun pelaporan kondisi baik } \\
\text { fisik maupun penggunaan peralatan (inventarisasi) }\end{array}$ \\
\hline
\end{tabular}

\subsection{Sistem dan teknologi saat ini}

Pada tahapan ini bertujuan untuk mendokumentasikan dan mendefeniskan semua platform sistem dan teknologi yang ada di STIMIKOM Stella Maris Sumba. Saat ini STIMIKOM Stella Maris Sumba belum menerapkan teknologi informasi dan sistem informasi dalam menjalankan proses bisnisnya atau dapat juga dikatakan bahwa semua aktivitas bisnis yang dilakukan masih menggunakan aplikasi standart (word dan excel). 
JURNAL MEDIA INFORMATIKA BUDIDARMA, Vol 3, No 3, Juli 2019

ISSN 2614-5278 (media cetak)

ISSN 2548-8368 (media online)

Hal 208-216 | DOI: 10.30865/mib.v3i3.1202

\subsection{Pemodelan arsitektur}

Pada pemodelan arsetektur ini, terdiri dari 3 tahap meliputi pemodelan arsitektur data, pemodelan arstektur aplikasi dan pemodelan arsitektur teknologi.

\subsubsection{Pemodelan arsitektur data}

Merupakan tahapan yang digunakan untuk mendefenisikan jenis-jenis data utama yang diperoleh dari proses dekomposisi proses bisnis. Berikut ini penjabaran dari jenis-jenis data pada tabel berikut ini.

Tabel 3. Entitas data

\begin{tabular}{cll}
\hline No & \multicolumn{1}{c}{ Entitas Bisnis } & \multicolumn{1}{c}{ Entitas Data } \\
\hline $1 \quad$ Penerimaan Mahasiswa Baru & Entitas Panitia PMB \\
& Entitas Biaya Pendaftaran \\
& Entitas Pendaftaran MABA \\
& Entitas calon MABA \\
& Entitas Seleksi masuk \\
& Entitas hasil seleksi \\
& Entitas Pendaftaran ulang \\
\hline Operasional kademik & Entitas Dosen \\
& Entitas Mahasiswa \\
& Entitas Kalender Akademik \\
& Entitas Kurikulum \\
& Entitas Matakuliah \\
& Entitas Registrasi Semester \\
& Entitas Ruang Kuliah \\
& Entitas Jurusan \\
& Entitas Kelas perkuliahan \\
& Entitas FRS (Form Rencaa Studi) \\
& Entitas Jadwal Perkuliahan \\
& Entitas Presensi Kuliah \\
& Entitas Ujian Tengah Semester \\
& Entitas Ujian Akhir Semester \\
& Entitas KHS \\
& Entitas Data pendaftaran skripsi \\
& Entitas pengajuan judul TA (skripsi) \\
& Entitas seminar proposal TA (skripsi) \\
& Entitas dosen Pembimbing TA (skripsi) \\
\hline & Entitas Jadwal Wisuda \\
& Entitas Pendaftaran Wisuda \\
& Entitas Transkrip Nilai \\
& Entitas Ijazah \\
& Entitas Tahun Lulus \\
&
\end{tabular}

\subsubsection{Pemodelan arsitektur aplikasi}

Pada tahapan pemodelan arsitektur aplikasi ini bertujuan untuk mendefenisikan jenis-jenis aplikasi-aplikasi utama untuk mendukung aktivitas akademik di STIMIKOM Stella Maris Sumba. Berikut ini tabel nama jenis aplikasi yang diusulkan.

Tabel 4. Arsitektur Aplikasi

\begin{tabular}{cccl}
\hline \multirow{2}{*}{ No } & \multirow{2}{*}{ Fungsi Bisnis } & ID & \multicolumn{1}{c}{ Nama Aplikasi } \\
\hline \multirow{3}{*}{1} & \multirow{3}{*}{ Penerimaan Mahasiswa Baru } & APL-1 & Aplikasi Pendaftaran Mahasiswa Baru \\
& & APL-2 & Aplikasi Seleksi PMB \\
& APL-3 & Aplikasi Pendaftaran Ulang \\
\hline \multirow{3}{*}{2} & APL-4 & Aplikasi Kalender Akedemik \\
& & APL-5 & Aplikasi Kurikulum \\
& & APL-6 & Aplikasi Data Mahasiswa \\
& \multirow{3}{*}{ Oprasioonal Akademik } & APL-7 & Aplikasi Daftar Matakuliah \\
& APL-8 & Aplikasi Jadwal PBM \\
& APL-9 & Aplikasi Presensi Mahasiswa \\
& & APL-10 & Aplikasi KRS \\
\hline
\end{tabular}




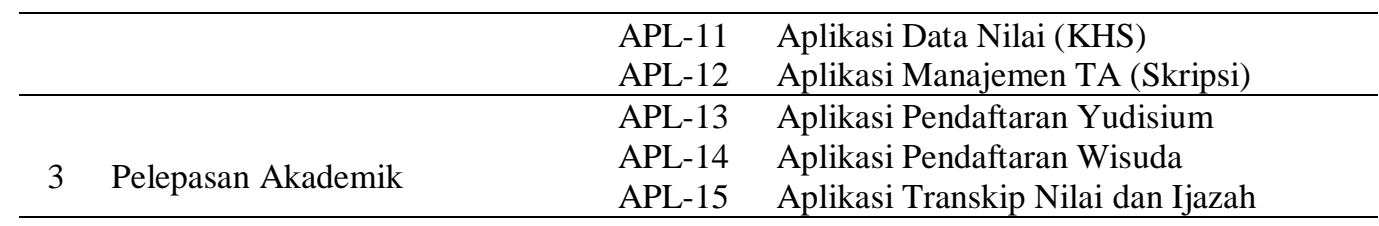

\subsubsection{Pemodelan arsitektur teknologi}

Pada pemodelan arsitektur teknologi ini dibagi menjadi 2 (dua) bagian diantaranya:

a. Model arsitektur teknologi informasi

Arsitektur teknologi informasi yang merupakan model konseptual teknologi informasi yang terdiri dari manajemen teknologi informasi yang berfungsi untuk mengontrol dan mengelola infrastruktur teknologi informasi, Klien (pengguna), perangkat pengoperasian yang digunakan, aplikasi, server, jaringan dan keamanan jaringan
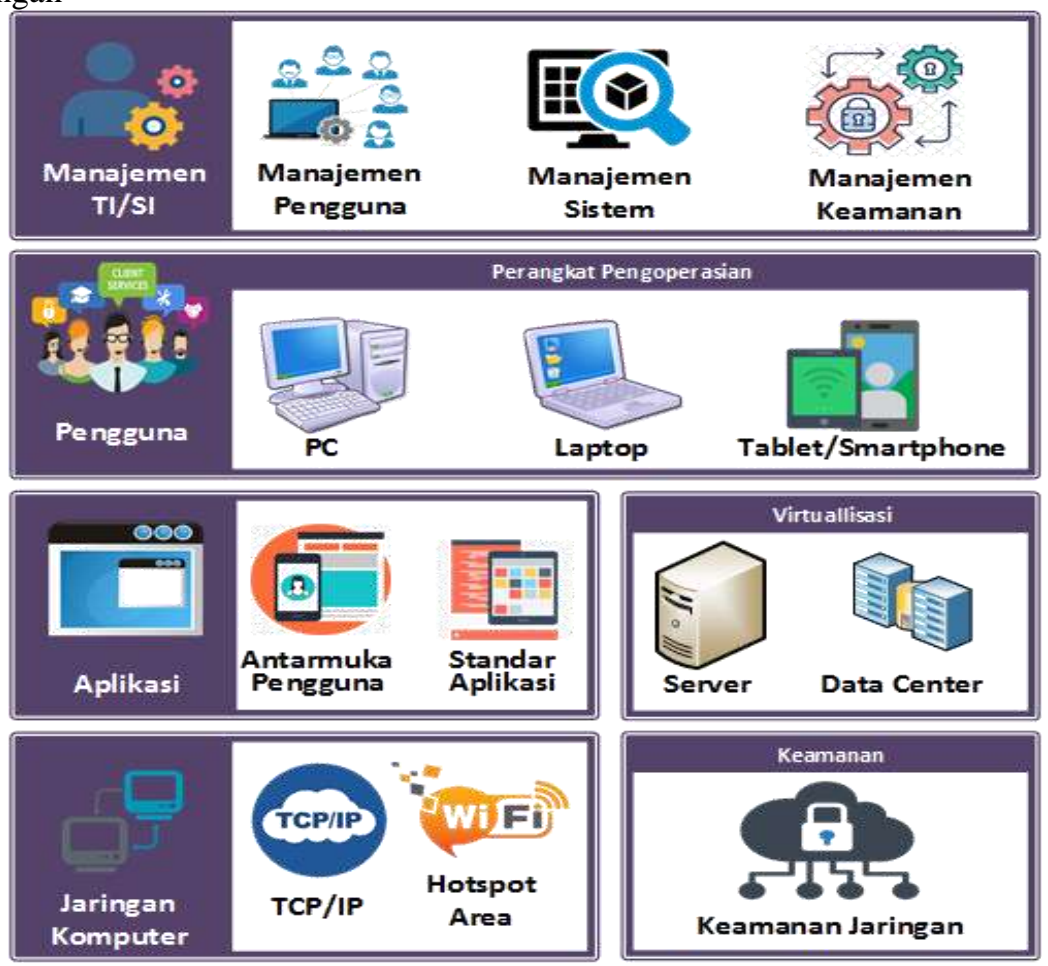

Gambar 7. Model Konseptual Arsitektur Teknologi Informasi

b. Pemodelan arsitektur jaringan

Pemodelan arsitektur jaringan yang menghubungkan unit kerja dengan para stakeholder di STIMIKOM Stella Maris Sumba dalam mengkomunikasikan data atau informasi antar unit maupun dengan mahasiswa. Berikut ini model arsitektur jaringan yang diusulkan seperti pada gambar 8 .

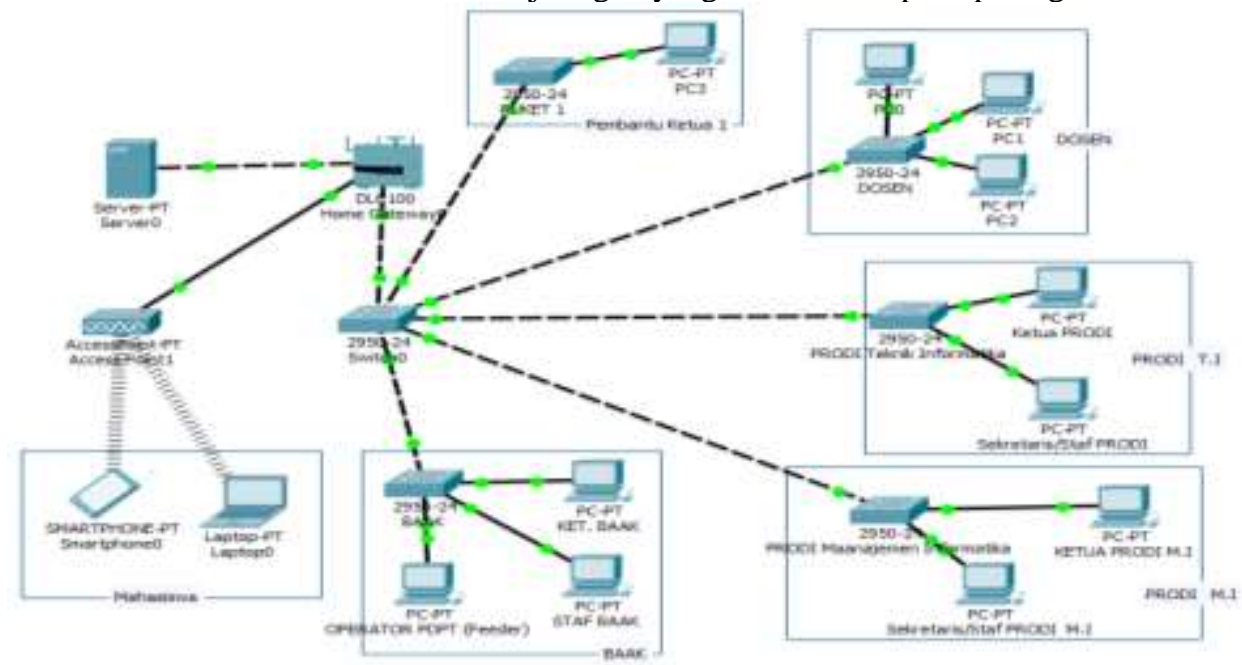

Gambar 8. Model Arsitektur Jaringan 


\section{IMPLEMENTASI}

Urutan implementasi pembangunan aplikasi disusun sesuai dengan tingat kebutuhan aplikasi dalam mendukung aktivitas akademik (potensial untuk didahulukan). Berikut ini roadmap usulan untuk pembangunan atau pengembangan sistem informasi.

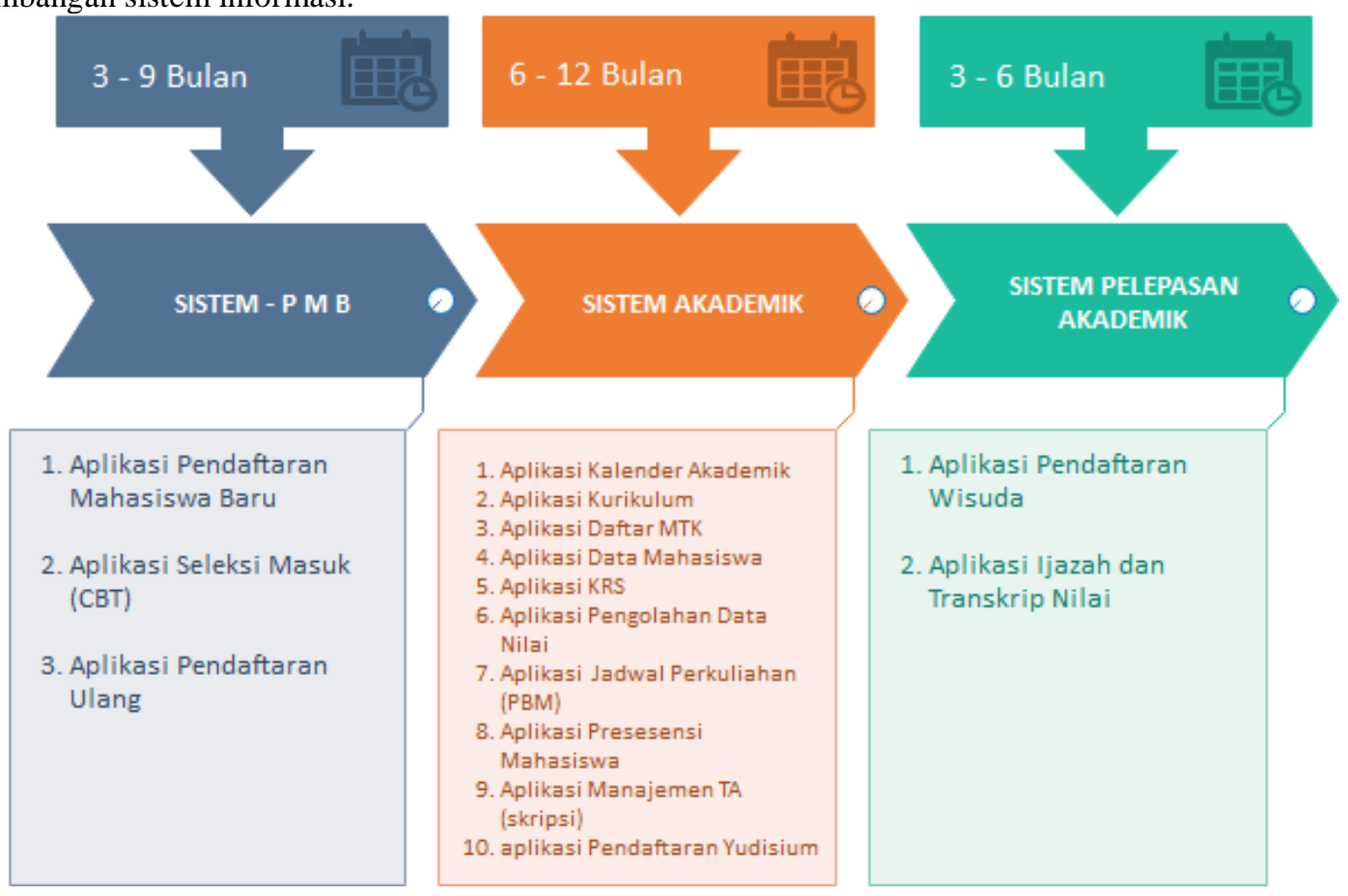

Gambar 9. Roadmap rencana Implementasi

\section{KESIMPULAN}

Berdasarkan hasil dan pembahasan yang telah dijabarkan, maka dapat disimpulkan bahwa :

a. Metodologi EAP yang digunakan dalam memodelkan arsitektur sistem informasi ini dapat menghasilkan rancangan asrsitektur sesuai dengan kebutuhan dari STIMIKOM Stella Maris Sumba guna guna menigkatkan pelayanan administrasi yang khususya peda pelaksanaan akademik

b. Pada pemdodealah arsitektur ini hanya berfokus pada kegitan akademik sehingga belum tersedia model arstektur untuk unit kerja yang lain

c. Hasil dari pemodelan arsitektur ini dapat diguanakan sebagai acuan atau pandulan dalam membangun sistem informasi untuk mendukung aktivitas akademik di STIMIKOM Stella Maris Sumba.

\section{REFERENCES}

[1] W. Wikusna, "Enterprise Architecture Model for Vocational High School," IJAIT, vol. 2, no. 1, pp. 22-28, 2018.

[2] J. A. Zachman, "About the Zachman Framework," Zachman International, Inc., Jan 2008. [Online]. Available: https://www.zachman.com/about-the-zachman-framework. [Diakses 6 Jun 2019].

[3] M. Hidayat, "Penyusunan Rencana Strategis STKIP PGRI Banjarmasin Menggunakan Enterprise Architecture Planning," JTERA, vol. 2, no. 2, pp. 63-72, 2017

[4] S. H. Spewak, Enterprise Architecture Planning (Developing a Blueprint for Data, Application and Technology), 1992.

[5] M. Zhang, H. Chen dan A. Luo, "A Systematic Review of Business-IT Alignment Research With Enterprise Architecture," IEEE, vol. 6, pp. 18933-18944, April 2018.

[6] H. Plessius, M. v. Steenbergen, R. Slot dan J. Versendaal, "The Enterprise Architecture Value Framework," dalam AIS Electronic Library (AISeL), Portsmouth, 2018.

[7] M. E. Porter dan M. R. Kramer, "The Big Idea: Creating Shared Value. How to reinvent capitalism and unleash a wave of innovation and growth," dalam Harvard Business Review, Springer, Dordrecht, 2011, pp. 1-17.

[8] H. A. Mumtahana, W. W. Winarno dan A. Sunyoto, "Perancangan Master Plan Sistem Informasi Akademik STT Dharma Iswara Madiun," Khazanah Informatika, vol. II, no. 2, pp. 72-84, 2016. 